\title{
Characterization of a novel large deletion and single point mutations in the BRCAI gene in a Greek cohort of families with suspected hereditary breast cancer
}

\author{
Ioulia Belogianni ${ }^{\dagger 1}$, Angela Apessos ${ }^{\dagger 1}$, Markos Mihalatos ${ }^{1}$, Evangelia Razi ${ }^{2}$,
} Stefanos Labropoulos ${ }^{2}$, Andreas Petounis ${ }^{2}$, Vasiliki Gaki ${ }^{3}$, Antonios Keramopoulos ${ }^{3}$, Nikos Pandis ${ }^{4}, K_{\text {Kriacos Kyriacou }}^{5}$, Andreas Hadjisavvas ${ }^{5}$, Paris Kosmidis ${ }^{6}$, Drakoulis Yannoukakos ${ }^{7}$ and Georgios Nasioulas*1

\begin{abstract}
Address: ${ }^{1}$ Molecular Biology Research Center HYGEIA «Antonis Papayiannis», DTCA HYGEIA, 15123 Maroussi, Athens, Greece, ${ }^{2} 1$ st Pathology Oncology Clinic, DTCA HYGEIA, 15123 Maroussi, Athens, Greece, ${ }^{3}$ Breast Cancer Unit, Iaso Women's Hospital, 15123 Maroussi, Greece, ${ }^{4}$ Department of Genetics, "Saint Savas" Anticancer Hospital, 11522 Athens, Greece, ${ }^{5}$ Department of Electron Microscopy/Molecular Pathology, The Cyprus Institute of Neurology and Genetics, 1683 Nicosia, Cyprus, ${ }^{62}$ nd Pathology - Oncology Clinic, DTCA HYGEIA, 15123 Maroussi, Athens, Greece and 7Molecular Diagnostics Lab, I/R-RP, National Center for Scientific Research "Demokritos" 15310 Athens, Greece

Email: Ioulia Belogianni - Iolia.Beloyianni@hygeia.gr; Angela Apessos - a.apessos@hygeia.gr; Markos Mihalatos - m.mihalat@hygeia.gr; Evangelia Razi - e.razis@hygeia.gr; Stefanos Labropoulos - slabropoulos@yahoo.com; Andreas Petounis - a.petouni@hygeia.gr;

Vasiliki Gaki - zervosk@otenet.gr; Antonios Keramopoulos - g-vourli@hotmail.gr; Nikos Pandis - nikos.pandis@medgen.ath.forthnet.gr; Kyriacos Kyriacou - kyriacos@cing.ac.cy; Andreas Hadjisavvas - kyriacos@cing.ac.cy; Paris Kosmidis - parkosmi@otenet.gr; Drakoulis Yannoukakos - yannouka@rrp.demokritos.gr; Georgios Nasioulas* - g.nasioul@ hygeia.gr

* Corresponding author †Equal contributors
\end{abstract}

Published: 07 September 2004

BMC Cancer 2004, 4:6I doi:|0.|I|86/|47|-2407-4-6I

This article is available from: http://www.biomedcentral.com/I47I-2407/4/6I

(c) 2004 Belogianni et al; licensee BioMed Central Ltd.

This is an open-access article distributed under the terms of the Creative Commons Attribution License (http://creativecommons.org/licenses/by/2.0), which permits unrestricted use, distribution, and reproduction in any medium, provided the original work is properly cited.
Received: 08 June 2004

Accepted: 07 September 2004

\begin{abstract}
Background: Germline mutations in BRCAI and BRCA2 predispose to breast and ovarian cancer. A multitude of mutations have been described and are found to be scattered throughout these two large genes. We describe analysis of $B R C A I$ in 25 individuals from 18 families from a Greek cohort.

Methods: The approach used is based on dHPLC mutation screening of the BRCAI gene, followed by sequencing of fragments suspected to carry a mutation including intron - exon boundaries. In patients with a strong family history but for whom no mutations were detected, analysis was extended to exons 10 and II of the BRCA2 gene, followed by MLPA analysis for screening for large genomic rearrangements.

Results: A pathogenic mutation in BRCAI was identified in 5/I8 (27.7 \%) families, where four distinct mutations have been observed. Single base putative pathogenic mutations were identified by dHPLC and confirmed by sequence analysis in 4 families: 5382 insC (in two families), GI738R, and 5586G > A (in one family each). In addition, 18 unclassified variants and silent polymorphisms were detected including a novel silent polymorphism in exon II of the BRCA I gene. Finally, MLPA revealed deletion of exon 20 of the BRCAl gene in one family, a deletion that encompasses $3.2 \mathrm{~kb}$ of the gene starting $2 \mathrm{I}$ bases into exon 20 and extending $3.2 \mathrm{~kb}$ into intron 20 and leads to skipping of the entire exon 20. The 3' breakpoint lies within an AluSp repeat but there are no recognizable
\end{abstract}


repeat motifs at the 5 ' breakpoint implicating a mechanism different to Alu-mediated recombination, responsible for the majority of rearrangements in the BRCAI gene.

Conclusions: We conclude that a combination of techniques capable of detecting both single base mutations and small insertions / deletions and large genomic rearrangements is necessary in order to accurately analyze the BRCAI gene in patients at high risk of carrying a germline mutation as determined by their family history. Furthermore, our results suggest that in those families with strong evidence of linkage to the BRCA I locus in whom no point mutation has been identified reexamination should be carried out searching specifically for genomic rearrangements.

\section{Background}

Germ line mutations in the BRCA1 and BRCA2 genes predispose individuals to breast and ovarian cancer. The lifetime risk of breast cancer in female carriers of a BRCA1 mutation is $60-80 \%$ while that of ovarian cancer is $20-$ $40 \%$. The median age of diagnosis of breast cancer is 42 years, i.e. 20 years earlier than the median of unselected women in the U.S.A. and Western Europe [1]. BRCA1 is a large gene with 22 coding exons encoding a $220 \mathrm{kD}$ protein [2] that functions in maintaining genomic integrity and in transcriptional regulation $[3,4]$.

A multitude of mutations scattered throughout the 5592 bp coding sequence have been described. In particular, germ line mutations in BRCA1 have been identified in $15-20 \%$ of women with a family history of breast cancer and $60-80 \%$ of women with a family history of breast and ovarian cancer $[5,6]$. The percentage of mutations identified is strongly dependent on the population studied, with strong founder effects evident in some populations [7-9]. The vast majority of mutations described to date are point mutations and small insertions and deletions http:/ /research.nhgri.nih.gov/bic/. Such mutations are detected by PCR-based screening methods such as the Protein Truncation Test (PTT), Single Strand Conformational Polymorphism (SSCP), Denaturing Gradient Gel Electrophoresis (DGGE), heteroduplex analysis (HA) and more recently denaturing high performance liquid chromatography (dHPLC) with varying degrees of sensitivity for each method. Direct DNA sequencing is used in order to confirm and characterize mutations detected by any of these approaches $[10,11]$. While in the early studies for mutation detection only single point or small insertion/deletion mutations were screened for, recent studies have shown that genomic rearrangements are also a common type of mutation in the two genes accounting for 10-30\% of all mutations identified in some populations [12-16].

In this study we document and extend previous work suggesting the necessity of screening for large genomic rearrangements in a complete program for mutation detection of the BRCA1 gene by characterizing a deletion encompassing $3.2 \mathrm{~kb}$ of the gene including exon 20. In addition, we add more evidence supporting pathogenicity of a pre- viously described variant, G1738R, which seems to be specific to the Greek population [17].

\section{Methods Patients}

BRCA1 patients and their families were referred through the Oncology Departments of Hygeia Hospital and other hospitals throughout Greece. Patients were included on the basis of affected family members, types of cancer present in the family and the age at diagnosis of breast cancer in the proband. The families were subdivided into high risk when multiple cases of breast and ovarian cancer were diagnosed, medium risk if there were only 2-3 cases of breast cancer, and low risk in isolated cases of breast cancer with diagnosis before the age of 40 years. The study population consisted therefore of 12 high risk families, 2 with medium risk, and 4 families at low risk as determined by their cancer history. Ethical approval was obtained from the hospital's advisory committee and all patients signed informed consent. Screening has been completed in 25 individuals from 18 families. Testing was initially carried out on DNA from an affected family member and upon detection of an inactivating mutation the rest of the family members were directly tested for this mutation.

\section{DNA and RNA isolation}

Genomic DNA and RNA were purified from peripheral blood leukocytes using standard extraction protocols.

\section{PCR amplification}

The complete coding sequence of BRCA1 including splice junctions was amplified by PCR. Similarly, exons 10 and 11 of the BRCA2 gene were amplified in 3 of the patients. Primers used have been chosen from the BIC database http://www.nhgri.nih.gov/Intramural research/

Lab_transfer/Bic/. In addition primers: mBRCAF: GAG TTT GTG TGT GAA CGG ACA CTG and mBRCAR: GTG CCA AGG GTG AAT GAT GAA AGC, designed during the course of this study, were used for amplification of cDNA from the patients found to carry a deletion of exon 20 of the BRCA1 gene. 
Reactions of $50 \mu \mathrm{l}$ were heated on a PTC-200 MJ Research Thermocycler (MJ Research Inc., USA) at $95^{\circ} \mathrm{C}$ for $5 \mathrm{~min}$ then cycled 35 times of denaturation at $95^{\circ} \mathrm{C}$ for $40 \mathrm{sec}$ annealing at the appropriate temperature for $30 \mathrm{sec}$ and extension at $72^{\circ} \mathrm{C}$ for $30 \mathrm{sec}$, followed by a final extension step at $72^{\circ} \mathrm{C}$ for $6 \mathrm{~min}$. Reaction mixture was $20 \mathrm{mM}$ TrisHCl (pH 8.4), $50 \mathrm{mM} \mathrm{KCl}, 1.5 \mathrm{mM} \mathrm{MgCl}_{2}, 200 \mu \mathrm{M}$ each dNTP, 1.5 U Taq DNA polymerase (Invitrogen, Netherlands) or 2.5 U Optimase polymerase (Transgenomic, Inc., USA) and 12.5 pmol of each primer.

\section{dHPLC analysis}

The WAVE DNA Fragment Analysis System (Transgenomic, Inc., USA) and associated WAVE-Maker ${ }^{\mathrm{TM}}$ software were used as previously described [18].

\section{Sequence analysis}

Purification of the PCR products was performed using the Concert Rapid PCR purification or gel extraction system kits (Marligen Biosciences INC, U.S.A.). Automated cycle sequencing for both strands was performed with the $\mathrm{ABI}$ Prism ${ }^{\circledast} 10$ Genetic Analyzer using the Big-Dye Terminator Cycle Sequencing Kit. Sequences obtained were aligned, using Sequencher ${ }^{\circledR}$ PC software, with normal sequences from Genbank (BRCA1: L78833, BRCA2: U43746) and examined for the presence of mutations. All nucleotide numbers refer to the wild-type cDNA sequence of BRCA1 as reported in GenBank (accession number U14680).

\section{Multiplex Ligation - dependent PCR Amplification (MLPA)}

MLPA was carried out using the P002_BRCA1 kit (MRCHolland, Netherlands) as instructed by the manufacturer. Fragment analysis was carried out on ABI Prism ${ }^{\circledR} 310$ Genetic Analyzer (Applied Biosystems, USA) using TAMRA-500 (Applied Biosystems, USA) as size standard. A peak pattern of 34 peaks ranging in size from 127 to 454 nt is obtained [19].

\section{Long PCR}

The deletion in BRCA1 exon 20 was confirmed by long PCR using the GeneAmp XL PCR System (Applied Biosystems, U.S.A.) according to the manufacturer's instructions. PCR was carried out in $50 \mu \mathrm{l}$ reactions consisting of $1 \times$ buffer II (supplied with the enzyme), 12 pmole each primer, $0.2 \mathrm{mM}$ each dNTP and 2.4 U rTth DNA polymerase, XL (Applied Biosystems, U.S.A.). After 2.5 min denaturation at $95^{\circ} \mathrm{C} \mathrm{PCR}$ was carried out for 19 cycles of $95^{\circ} \mathrm{C}$ for $30 \mathrm{sec}, 58^{\circ} \mathrm{C}$ for $30 \mathrm{sec}$ and $68^{\circ} \mathrm{C}$ for $8 \mathrm{~min}$ followed by 15 cycles of $95^{\circ} \mathrm{C}$ for $30 \mathrm{sec}, 58^{\circ} \mathrm{C}$ for $30 \mathrm{sec}$ and $68^{\circ} \mathrm{C}$ for $4 \mathrm{~min}$ with a time increment of $10 \mathrm{sec}$ per cycle. A final extension step was carried out at $72{ }^{\circ} \mathrm{C}$ for $10 \mathrm{~min}$. PCR products were separated by agarose gel electrophoresis and visualized by EtBr staining.

\section{RT-PCR}

Total RNA was extracted from whole blood of patients from family D using Trizol (Life Technologies, USA) according to the manufacturer's instructions. First strand synthesis was performed by denaturing approximately 500 - 1000 ng total RNA, random hexamers $(5 \mu \mathrm{M}$ final concentration) for $4 \mathrm{~min}$ at $70^{\circ} \mathrm{C}$, followed by snap freezing on ice and addition of dNTPs $(0.5 \mathrm{mM}$ final concentration), $1 \mathrm{U} / \mu \mathrm{l}$ recombinant $\mathrm{RNase}$ inhibitor (Invitrogen, Netherlands) and 200 U MMLV reverse transcriptase (Invitrogen, Netherlands). The mixture was incubated at $37^{\circ} \mathrm{C}$ for 1 hour followed by denaturation of the enzymes at $95^{\circ} \mathrm{C}$ for $5 \mathrm{~min} .4 \mu \mathrm{l}$ of cDNA were used for subsequent PCR amplification.

\section{Results}

A total of 18 families, 12 of which were at high risk of having hereditary breast cancer, have been examined for mutations at the BRCA1 locus. A pathogenic mutation was identified in five families, where four distinct mutations have been observed. In addition, 18 polymorphisms, including a novel silent polymorphism in exon 11 of the BRCA1 gene, have been detected (Table 1). Furthermore, in 3 of the families exons 10 and 11 of BRCA2 were analyzed. Table 1 summarizes the results of single nucleotide variants detected in this study. All of the variants have been identified by dHPLC and characterized by sequencing.

In family A there were four cases of breast cancer affecting four successive generations. The proband was diagnosed with breast cancer at the age of 45 . The most frequently occurring mutation, 5382insC in exon 20, was identified. Analysis of the proband's daughter in whom cancer developed at the age of 38 revealed that she also carried the mutation. The same mutation was also identified in family E where breast cancer was diagnosed in 3 members in three successive generations at 42, 37 and 41 years (data not shown).

In family B there were seven cases of breast cancer and one case of colorectal cancer at age 50. Mutation analysis at the BRCA1 locus revealed a missense mutation $5331 \mathrm{G}>\mathrm{A}$. The mutation results in substitution of a Glycine by an Arginine at codon 1738. The mutation was not detected in the patient's unaffected sister. Unfortunately, no other family members were available for analysis.

In family $\mathrm{C}$ there were 4 cases of breast cancer in addition to cancer of the larynx, ovaries, lung and the genitals. A single base substitution, G > A at nucleotide 5586 was identified. This mutation causes a splicing defect resulting in a protein lacking exon 23. Unfortunately, no DNA was available from other family members in order to test the correlation of this mutation with the other tumor types. 
Table I: Variants identified in the BRCAI and BRCA2 genes during this study.

\begin{tabular}{|c|c|c|c|c|c|c|}
\hline \multicolumn{7}{|c|}{ Mutation } \\
\hline Family No & Total No of $\mathrm{CaBr}^{\mathrm{I}}$ & No of $\mathrm{CaOv}^{2}$ cases & Exon & Nucleotide & Effect & $\begin{array}{l}\text { Other cancers } \\
\text { (age at onset) }\end{array}$ \\
\hline $\mathbf{A}$ & 4 & - & 20 & 5382ins C & $\mathrm{Fs}^{3}$ & - \\
\hline B & 7 & - & 20 & $5331 \mathrm{G}>\mathrm{A}$ & GI738R & Colorectal (50) \\
\hline C & 4 & 1 & 23 & $5586 \mathrm{G}>\mathrm{A}$ & Splicing & Larynx Lungs Genitalia \\
\hline D & 5 & - & 20 & $\begin{array}{l}\text { Deletion of the } \\
\text { entire exon }\end{array}$ & $\begin{array}{l}\text { Protein missing } 20 \text { a.a. of } \\
\text { the BRCT-linker domain }\end{array}$ & Colorectal \\
\hline $\mathbf{E}$ & 3 & - & 20 & 5382ins C & $\mathrm{Fs}^{3}$ & - \\
\hline
\end{tabular}

Benign polymorphisms

\begin{tabular}{|c|c|c|c|c|c|}
\hline & Exon & Codon & Nucleotide Change & Consequences & No of families \\
\hline \multirow[t]{14}{*}{ BRCAI } & IVS 4 & IVS4-19 & $C>A$ & - & 1 \\
\hline & IVS 7 & IVS7-34 & $C>T$ & - & 2 \\
\hline & II & 693 & $2196 G>A$ & Asp $>$ Asn & 2 \\
\hline & & 694 & $220 I C>T$ & Ser $>$ Ser & 5 \\
\hline & & 771 & $2430 \mathrm{~T}>\mathrm{C}$ & Leu $>$ Leu & 6 \\
\hline & & 871 & $273 \mid C>T$ & Pro $>$ Leu & 3 \\
\hline & & 1038 & $3232 A>G$ & Glu $>$ Gly & 7 \\
\hline & & 1040 & $3238 G>A$ & Ser $>$ Asn & 1 \\
\hline & & $1145^{4}$ & $3544 \mathrm{~T}>\mathrm{C}$ & Val > Val & $\mathbf{I}$ \\
\hline & & 1150 & $3567 C>T$ & Pro $>$ Ser & 1 \\
\hline & & 1183 & $3667 A>G$ & Lys $>$ Arg & 7 \\
\hline & 13 & 1436 & $4427 \mathrm{~T}>\mathrm{C}$ & Ser $>$ Ser & 4 \\
\hline & 16 & 1613 & $4956 \mathrm{~A}>\mathrm{G}$ & Ser > Gly & 1 \\
\hline & 24 & 1829 & $5606 \mathrm{G}>\mathrm{A}$ & Glu $>$ Glu & 2 \\
\hline \multirow[t]{4}{*}{ BRCA2 } & 10 & 372 & $1342 A>C$ & Asn $>$ His & 1 \\
\hline & II & 1132 & $3624 A>G$ & Lys $>$ Lys & 2 \\
\hline & & 1269 & $4053 \mathrm{~T}>\mathrm{C}$ & $\mathrm{Val}>\mathrm{Val}$ & 1 \\
\hline & 14 & 2414 & $7470 A>G$ & Ser $>$ Ser & 1 \\
\hline
\end{tabular}

I $\mathrm{CaBr}=$ Breast Cancer

${ }^{2} \mathrm{CaOv}=$ Ovarian Cancer

${ }^{3} \mathrm{fs}=$ frame-shift mutation

${ }^{4}$ novel polymorphism identified in this study

In Family D (Figure 1a) there were 5 cases of breast cancer with age at onset ranging from 29 to 50 years. In addition there was one individual who had CRC. Sequencing of the complete coding region of BRCA1, failed to reveal a mutation. This prompted the analysis of other genes, namely $B R C A 2$ and $p 53$ in order to try and characterize the phenotype in this family, but no mutation was identified. For this reason, we decided to use the MLPA technique [19] to screen the proband for genomic rearrangements which have been shown to be responsible for a large proportion of BRCA1 mutations. MLPA analysis of the proband (IV:10 in figure 1a) revealed deletion of exon 20 of the BRCA1 gene. This was confirmed by Long PCR (Figure 1b) and RT - PCR. Sequencing of PCR products generated by RT-PCR confirmed absence of the entire exon 20 in the mRNA of the patient. Subsequently, a number of restric- tion endonucleases were employed in order to narrow down the deletion breakpoints and facilitate their characterization. A SmaI-generated irregular fragment was finally isolated from agarose gel and sequenced revealing a deletion of $3.2 \mathrm{~kb}$ starting 21 bases into exon 20 and extending $3.2 \mathrm{~kb}$ into intron 20 (Figure 1c). The 3' breakpoint lies within an AluSp repeat but there are no recognizable repeat motifs at the 5' breakpoint. The deletion was also found in 4 relatives of the proband (Figure 1a) who were tested, two of whom had breast cancer. The other two relatives had not yet developed cancer at the ages of 36 and 55 at the time of testing and are therefore assumed to be pre - symptomatic carriers. Finally, the proband's sister, who at the time of testing had not developed cancer at the age of 33 was found not to carry the mutation. 


\section{A}
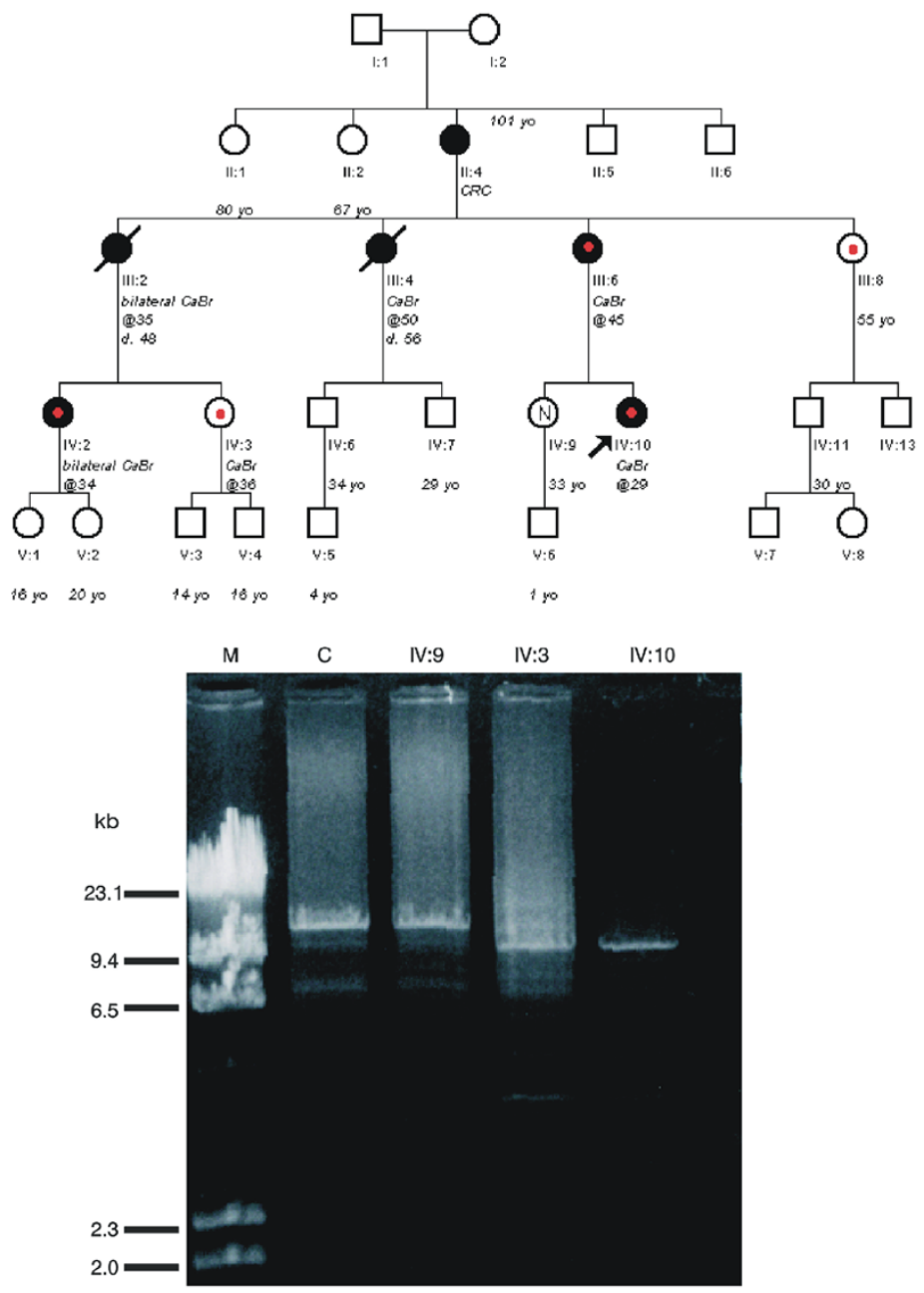

C
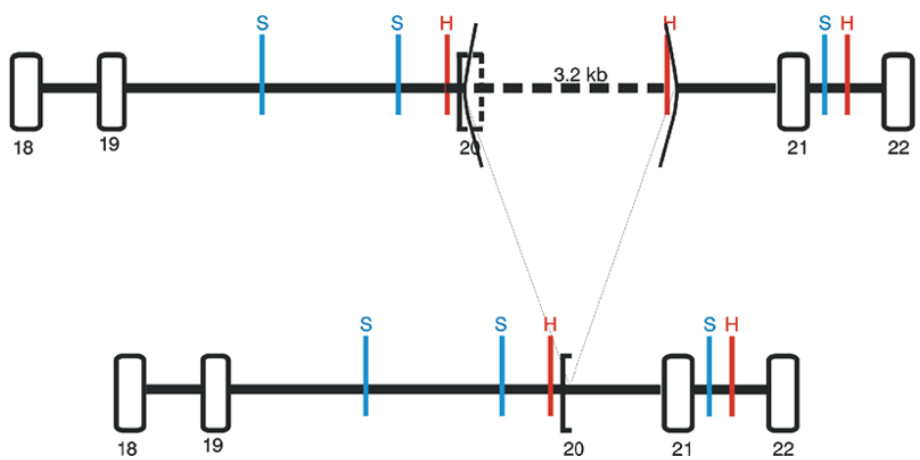

\section{Figure I}

Family $D$ in whom deletion of exon 20 of the BRCA I gene was detected. a. Pedigree of family D. Black symbols indicate individuals with cancer. The proband is indicated by an arrow. A red circle inside a symbol indicates individuals found to carry the mutation. $(\mathrm{CaBr}=$ breast cancer, $\mathrm{CRC}=$ colorectal cancer $\mathrm{d}$.=age of death, $\mathrm{N}=$ individual tested for the family mutation and was found to be of normal genotype). b. Long PCR of DNA from three individuals in family $D$. (M=molecular size marker ( $\lambda /$ HindIII, New England Biolabs, U.S.A.), $C=$ normal control, numbers denote the identifier in the pedigree). c. Schematic representation (not to scale) of the fragment of BRCAI gene amplified by Long PCR showing the position of exons, restriction endonuclease cleavage sites and the deletion. Empty boxes indicate exons. Vertical colored bars indicate restriction sites: blue $(\mathrm{S})=\mathrm{Smal}$. $\operatorname{Red}(\mathrm{H})=$ HindlII. 


\section{Discussion}

A total of 18 breast cancer families have been examined for mutations at the BRCA1 locus. In three of the families analysis was extended to exons 10 and 11 of the BRCA2 gene. A pathogenic mutation in BRCA1 was identified in $5 / 18(27.7 \%)$ families, where four distinct mutations have been observed. In addition, 18 polymorphisms have been found to be present in more than one family.

In family B a missense mutation, $5331 \mathrm{G}>\mathrm{A}$, was identified. The exact effect of this single amino acid change, G1738R, on the protein function is unclear. The altered glycine is located on the surface of the coil structure of the BRCT linker region and the mutation therefore may disrupt the interface or affect protein interaction [20]. This mutation has been previously described in 4 unrelated Greek patients [21]. An alternative mutation affecting the same amino acid, G1738E, has been shown to result in loss of function of the protein in vitro [22,23]. Based on this information, the family history of the individual described here and absence of the mutation in the proband's unaffected sister we hypothesize that the mutation is pathogenic although additional data are needed.

Our results indicate, as has been documented by others that family history is the major determinant of the risk of breast cancer. As can be seen in Table 1 in all families where a pathogenic mutation was identified there were at least 3 cases of breast cancer. In addition, the extremely high risk suggested by the family history in some cases prompted a more intense analysis of further genes and approaches in an attempt to characterize the underling reason for such a family history. This was the case in family $\mathrm{D}$ where sequencing of the complete coding region of $B R C A 1$, failed to reveal a mutation. This prompted the analysis of other genes, namely BRCA2 and p53, but without finding a mutation. For this reason, we decided to use the MLPA technique [19] to screen the proband for genomic rearrangements which have been shown to be responsible for a large proportion of BRCA1 mutations [12-16]. This led to the identification of deletion of an entire exon of the BRCA1 gene, namely exon 20.

Deletion of exon 20 has been previously described in an Italian family [12]. However, the authors of that report have localized the breakpoints of the deletion in the two flanking introns [12]. In the deletion described here the $5^{\prime}$ breakpoint is localized inside exon 20 (21 bp upstream of the splice donor site) while the 3' breakpoint is located $3.2 \mathrm{~kb}$ into intron 20 within an AluSp repeat. The deletion described here, therefore, is different to the majority of rearrangements described so far for the BRCA1 gene, since they have been shown to result from homologous recombination of $A l u$ repeats $[24,25]$. In this case, the 5' breakpoint does not correlate with any recognizable repeat motifs suggesting a repeat - independent recombination mechanism at play.

In $2 / 5$ pedigrees in whom a pathogenic mutation was identified there was one case each of colorectal cancer (CRC). In particular, in family D (Figure 1a) the disease seems to have originated from a CRC patient. Data on the correlation between BRCA1 mutations and the risk of CRC are not conclusive. Two recent studies carried out on Ashkenazi Jewish patients suggest that there is no correlation $[26,27]$. Other reports carried out on more diverse populations suggest 2- to 3-fold elevated risks of CRC among first-degree relatives of BRCA1 mutation carriers $[28,29]$. Unfortunately, there was no DNA available for analysis from the two CRC patients in the two families.

A further interesting point observed in this study is the identification of two BRCA1 unaffected mutation carriers at the ages of 39 and 55. The penetrance and age of onset of disease in BRCA1 mutation carriers is variable. Various reports have suggested the existence of modifying genetic and environmental factors on the penetrance of BRCA1 and BRCA2 mutation carriers [30,31]. In this respect it is interesting to examine this large pedigree for such modifying factors.

\section{Conclusions}

To our knowledge this is the first report of a genomic rearrangement identified as the underlying mutation of BRCA1 in a Greek family. Although our sample group is quite small identification of 1 genomic rearrangement in 5 mutations detected, suggests that in yet another population this type of mutations contribute to the BRCA1 mutation spectrum. This therefore warrants use of a combination of techniques capable of identifying both single base mutations in addition to large genomic rearrangements. In this respect, we have found that use of dHPLC for single base mutations and MLPA for large genomic rearrangements is a reliable combination for use as an initial screening step followed by sequencing for characterization of the mutations identified.

Furthermore, our results suggest that in those families with strong evidence of linkage to the BRCA1 locus in whom no point mutation has been identified re-examination should be carried out searching specifically for genomic rearrangements.

\section{List of abbreviations}

dHPLC denaturing High Performance Liquid Chromatography

MLPA Multiplex Ligation - dependent PCR Amplification

PCR Polymerase Chain Reaction 
RT-PCR Reverse Transcription Polymerase Chain Reaction

\section{CRC Colorectal Cancer}

\section{Competing interests}

None declared.

\section{Authors contributions}

IB carried out mutation detection by dHPLC and sequencing for the patients analyzed. AA carried out MLPA, the molecular characterization of the deletion, and drafted the manuscript. MM contributed in the molecular studies and preparation of the manuscript and figures, ER, SL, AP, VG, AK NP, PK and DY provided the patient material, diagnosis and management, $\mathrm{KK}$ and $\mathrm{AH}$ carried out molecular genetic analysis of the p53 gene, GN conceived of the study, and participated in its design and coordination. All authors read and approved the final manuscript.

\section{Acknowledgements}

This work is supported by STAVROS NIARCHOS FOUNDATION FOR CHARITY and by the Greek General Secretary for Research and Technology (8057/3I-5-200I).

\section{References}

I. Nathanson KN, Wooster R, Webber BL: Breast cancer genetics: What we know and what we need. Nature Medicine 2001, 7:552-556.

2. Miki Y, Swensen J, Shattuck-Eidens D, Futreal PA, Harshman K, Tavtigian S, Liu Q, Cochran C, Bennett LM, Ding W, Bell R, Rosenthal J, Hussey C, Tran T, McClure M, Frye C, Hattier T, Phelps R, HaugenStrano A, Katcher H, Yakumo K, Gholami Z, Shaffer D, Stone S, Bayer S, Wray C, Bogden R, Dayananth P, Ward J, Tonin P, Narod S, Bristow PK, Norris FH, Helvering L, Morrison P, Rosteck P, Lai M, Barrett JC, Lewis C, Neuhausen S, Cannon-Albright L, Goldgar D, Wiseman R, Kamb A, Skolnick MH: A strong candidate for the breast and ovarian cancer susceptibility gene BRCAI . Science |994, 266:66-7|.

3. Venkitaraman AR: Functions of BRCAI and BRCA2 in the biological response to DNA damage. Journal of Cell Science 200I, | | 4:359|-3598.

4. Deng C-X, Wang $\mathrm{R}-\mathrm{H}$ : Roles of BRCAI in DNA damage repair: a link between development and cancer. Human Molecular Genetics 2003, I 2:RII3-RI23.

5. Gayther SA, de Foy KA, Harrington P, Pharoah P, Dunsmuir WD, Edwards SM, Gillett C, Ardern-Jones A, Dearnaley DP, Easton DF, Ford D, Shearer RJ, Kirby RS, Dowe AL, Kelly J, Stratton MR, Ponder $B A$, Barnes D, Eeles RA: The frequency of germ-line mutations in the breast cancer predisposition genes BRCAI and BRCA2 in familial prostate cancer. The Cancer Research Campaign/British Prostate Group United Kingdom Familial Prostate Cancer Study Collaborators. Cancer Res 2000, 60:4513-4518.

6. Ford D, Easton DF, Stratton M, Narod S, Goldgar D, Devilee P, Bishop DT, Weber B, Lenoir G, Chang-Claude J, Sobol H, Teare MD, Struewing J, Arason A, Scherneck S, Peto J, Rebbeck TR, Tonin P, Neuhausen S, Barkardottir R, Eyfjord J, Lynch H, Ponder BA, Gayther SA, Zelada-Hedman M, and the Breast Cancer Linkage Consortium: Genetic heterogeneity and penetrance analysis of the BRCAI and BRCA2 genes in breast cancer families. The Breast Cancer Linkage Consortium. Am J Hum Genet 1998, 62:676-689.

7. Szabo $\mathrm{Cl}$, King MC: Population genetics of BRCAI and BRCA2. Am J Hum Genet 1997, 60:1013-1020.

8. Neuhausen SL: Ethnic differences in cancer risk resulting from genetic variation. Cancer 1999, 86:2575-2582.
9. Steinberg KK, Pernarelli JM, Marcus M, Khoury MJ, Schildkraut JM, Marchbanks PA: Increased risk for familial ovarian cancer among Jewish women: a population-based case-control study. Genet Epidemiol 1998, I 5:51-59.

10. Andrulis IL, Anton-Culver H, Beck J, Bove B, Boyd J, Buys S, Godwin AK, Hopper JL, Li F, Neuhausen SL, Ozcelik H, Peel D, Santella RM, Southey MC, van Orsouw NJ, Venter DJ, Vijg J, Whittemore AS, Cooperative Family Registry for Breast Cancer studies: Comparison of DNA- and RNA-based methods for detection of truncating BRCAI mutations. Hum Mutat 2002, 20:65-73.

II. Gross E, Arnold N, Goette J, Schwarz-Boeger U, Kiechle M: A comparison of BRCAI mutation analysis by direct sequencing, SSCP and DHPLC. Hum Genet 1999, 105:72-78.

12. Montagna M, Dalla Palma M, Menin C, Agata S, De Nicolo A, ChiecoBianchi L, D'Andrea E: Genomic rearrangements account for more than one-third of the BRCAI mutations in northern Italian breast/ovarian cancer families. Hum Mol Genet 2003, I 2: |055-|06|.

13. Barrois M, Bieche I, Mazoyer S, Champeme MH, Bressac-de Paillerets $B$, Lidereau R: Real-time PCR-based gene dosage assay for detecting BRCAI rearrangements in breast-ovarian cancer families. Clin Genet 2004, 65: I 3 I-I 36.

14. Casilli F, Di Rocco ZC, Gad S, Tournier I, Stoppa-Lyonnet D, Frebourg T, Tosi M: Rapid detection of novel BRCAI rearrangements in high-risk breast-ovarian cancer families using multiplex PCR of short fluorescent fragments. Hum Mutat 2002, 20:218-226.

15. Unger MA, Nathanson KL, Calzone K, Antin-Ozerkis D, Shih HA, Martin AM, Lenoir GM, Mazoyer S, Weber BL: Screening for genomic rearrangements in families with breast and ovarian cancer identifies BRCAI mutations previously missed by conformation-sensitive gel electrophoresis or sequencing. Am J Hum Genet 2000, 67:84I-850.

16. Puget N, Stoppa-Lyonnet D, Sinilnikova OM, Pages S, Lynch HT, Lenoir GM, Mazoyer S: Screening for germ-line rearrangements and regulatory mutations in BRCAI led to the identification of four new deletions. Cancer Res 1999, 59:455-46 I

17. Ladopoulou A, Kroupis C, Konstantopoulou I, loannidou-Mouzaka L, Schofield AC, Tsionou C, Panopoulos C, Mihalatos M, Nasioulas G, Skarlos D, Haites NE, Fountzilas G, Pandis N, Yannoukakos D: Germ line BRCAI and BRCA2 mutations in Greek breast/ovarian cancer families: 5382 ins $C$ is the most frequent mutation observed. Cancer Letters 2002, I 85:6I-70.

18. Mihalatos M, Apessos A, Triantafillidis JK, Kosmidis PA, Fountzilas G, Agnantis NJ, Yannoukakos D, Nasioulas G: Evaluation of dHPLC in Mutation Screening of the APC Gene in a Greek FAP Cohort. Anticancer Res 2003, 23:2691-2696.

19. Schouten JP, McElgunn C], Waaijer R, Zwijnenburg D, Diepvens F, Pals G: Relative quantification of $\mathbf{4 0}$ nucleic acid sequences by multiplex ligation-dependent probe amplification. Nucleic Acids Res 2002, 30:e57.

20. Huyton T, Bates PA, Zhang X, Sternberg MJ, Freemont PS: The BRCA I C-terminal domain: structure and function. Mutat Res 2000, 460:319-332.

21. Konstantopoulou I, Kroupis C, Ladopoulou A, Pantazidis A, Boumba D, Lianidou ES, Petersen MB, Florentin L, Chiotellis E, Nounesis G, Efstathiou E, Skarlos D, Tsionou C, Fountzilas G, Yannoukakos D: BRCAI mutation analysis in breast/ovarian cancer families from Greece. Hum Mutat 2000, 16:272-273.

22. Vallon-Christersson J, Cayanan C, Haraldsson K, Loman N, Bergthorsson JT, Brondum-Nielsen K, Gerdes AM, Moller P, Kristoffersson $U$, Olsson $H$, Borg A, Monteiro AN: Functional analysis of BRCAI C-terminal missense mutations identified in breast and ovarian cancer families. Hum Mol Genet 200I, I 0:353-360.

23. Hayes F, Cayanan C, Barilla D, Monteiro AN: Functional assay for BRCAI: mutagenesis of the COOH-terminal region reveals critical residues for transcription activation. Cancer Res 2000 , 60:24II-24I8.

24. Rohlfs EM, Puget N, Graham ML, Weber BL, Garber JE, Skrzynia C, Halperin JL, Lenoir GM, Silverman LM, Mazoyer S: An Alu-mediated 7.I kb deletion of BRCAI exons 8 and 9 in breast and ovarian cancer families that results in alternative splicing of exon I0. Genes Chromosomes Cancer 2000, 28:300-307.

25. Puget N, Sinilnikova OM, Stoppa-Lyonnet D, Audoynaud C, Pages S, Lynch HT, Goldgar D, Lenoir GM, Mazoyer S: An Alu-mediated 6- 
kb duplication in the BRCAI gene: a new founder mutation? Am J Hum Genet 1999, 64:300-302.

26. Kirchhoff T, Satagopan JM, Kauff ND, Huang H, Kolachana P, Palmer C, Rapaport H, Nafa K, Ellis NA, Offit K: Frequency of BRCAI and BRCA2 mutations in unselected Ashkenazi Jewish patients with colorectal cancer. I Natl Cancer Inst 2004, 96:68-70.

27. Niell BL, Rennert G, Bonner JD, Almog R, Tomsho LP, Gruber SB: BRCAI and BRCA2 founder mutations and the risk of colorectal cancer. J Natl Cancer Inst 2004, 96: I5-2I.

28. Brose MS, Rebbeck TR, Calzone KA, Stopfer JE, Nathanson KL, Weber BL: Cancer risk estimates for BRCAI mutation carriers identified in a risk evaluation program. J Natl Cancer Inst 2002, 94: $1365-1372$

29. Risch HA, McLaughlin JR, Cole DE, Rosen B, Bradley L, Kwan E, Jack E, Vesprini DJ, Kuperstein G, Abrahamson JL, Fan I, Wong B, Narod SA: Prevalence and penetrance of germline BRCAI and BRCA2 mutations in a population series of 649 women with ovarian cancer. Am J Hum Genet 200I, 68:700-7I0.

30. Rebbeck TR, Kantoff PW, Krithivas K, Neuhausen S, Blackwood MA, Godwin AK, Daly MB, Narod SA, Garber JE, Lynch HT, Weber BL, Brown M: Modification of BRCAI-associated breast cancer risk by the polymorphic androgen-receptor CAG repeat. Am J Hum Genet 1999, 64: I37I-I377.

31. Ginolhac SM, Gad S, Corbex M, Bressac-De-Paillerets B, Chompret A, Bignon YJ, Peyrat JP, Fournier J, Lasset C, Giraud S, Muller D, Fricker JP, Hardouin A, Berthet P, Maugard C, Nogues C, Lidereau R, Longy M, Olschwang S, Toulas C, Guimbaud R, Yannoukakos D, Szabo C, Durocher F, Moisan AM, Simard J, Mazoyer S, Lynch HT, Goldgar D, Stoppa-Lyonnet D, Lenoir GM, Sinilnikova OM: BRCAI wild-type allele modifies risk of ovarian cancer in carriers of BRCAI germ-line mutations. Cancer Epidemiol Biomarkers Prev 2003, I 2:90-95.

\section{Pre-publication history}

The pre-publication history for this paper can be accessed here:

http://www.biomedcentral.com/1471-2407/4/61/prepub

\section{Publish with Bio Med Central and every scientist can read your work free of charge}

"BioMed Central will be the most significant development for disseminating the results of biomedical research in our lifetime. "

Sir Paul Nurse, Cancer Research UK

Your research papers will be:

- available free of charge to the entire biomedical community

- peer reviewed and published immediately upon acceptance

- cited in PubMed and archived on PubMed Central

- yours - you keep the copyright 